\title{
Retraction Note to: Carboxypeptidase E: Elevated Expression Correlated with Tumor Growth and Metastasis in Pheochromocytomas and Other Cancers
}

\author{
Saravana R. K. Murthy ${ }^{1} \cdot$ Karel Pacak $^{2} \cdot$ Y. Peng Loh ${ }^{1}$ \\ Published online: 6 April 2020 \\ ๑) Springer Science+Business Media, LLC, part of Springer Nature 2020
}

\section{Retraction to: Cellular and Molecular Neurobiology (2010) 30:1377-1381 \\ https://doi.org/10.1007/s10571-010-9592-y}

The Editor and the Publisher have retracted this article [1] following an investigation by the National Institutes of Health (NIH) into the primary data used to construct Table 2. This investigation concluded that the data in Table 2 are unreliable.

\section{Reference}

1. Murthy SRK, Pacak K, Loh YP (2010) Carboxypeptidase E: elevated expression correlated with tumor growth and metastasis in pheochromocytomas and other cancers. Cell Mol Neurobiol 30:1377-1381. https://doi.org/10.1007/s10571-010-9592-y

Publisher's Note Springer Nature remains neutral with regard to jurisdictional claims in published maps and institutional affiliations.

The original article can be found online at https://doi.org/10.1007/ s10571-010-9592-y.

Y. Peng Loh lohp@mail.nih.gov

1 Section on Cellular Neurobiology, Program on Developmental Neuroscience, Eunice Kennedy Shriver National Institute of Child Health and Human Development, National Institutes of Health, Bldg. 49, Rm. 5A22, 49 Convent Drive, MSC 4480, Bethesda, MD 20892, USA

2 Reproductive and Adult Endocrinology Program, Eunice Kennedy Shriver National Institute of Child Health and Human Development, National Institutes of Health, Bethesda, MD 20892, USA 